\title{
Entre a farda e a minissaia: posições de sujeito em conflito
}

\author{
Sandra Depexe ${ }^{1}$
}

\begin{abstract}
Resumo
O consumo cultural de Néstor García Canclini é conjugado aos capitais de Pierre Bourdieu e à análise de discurso de Michel Pêcheux para a leitura da representação de classe na telenovela Salve Jorge (Rede Globo, 2012/2013), a partir dos comentários de receptores no Twitter sobre a personagem Érica (Flávia Alessandra). Como resultados, o imaginário de classe é articulado a um padrão estético hegemônico, o qual entra em conflito na trajetória da personagem: embora seu corpo seja visto pela audiência como um modelo ao consumo, seu usos são reprimidos e ela passa a ser designada pela recepção como "periguete".
\end{abstract}

\section{Palavras-chave}

Consumo cultural; Classe social; Análise de discurso.

\begin{abstract}
The cultural consumption of Néstor García Canclini is conjugated to the capitals of Pierre Bourdieu and to the discourse analysis of Michel Pêcheux for the reading of the representation of class in the telenovela Salve Jorge (RedeGlobo, 2012/2013), from the receivers' comments on Twitter about the character Érica (Flávia Alessandra). As the result, the idea of class is articulated to a hegemonic aesthetic standard, which conflicts during the character's story: although her body be seen by the audience as a consumption model, its practice is suppressed and she turns to be designed by the receivers as a "periguete".
\end{abstract}

\section{Keywords}

Cultural consumption; Social class; Discourse analysis.

\section{Introdução}

O interesse em investigar o consumo simultâneo da televisão e da internet - neste texto, da telenovela Salve Jorge (Rede Globo, 2012/2013) e do Twitter ${ }^{2}$ - e a construção de sentidos realizados por uma recepção conectada, vem ao encontro da tendência contemporânea de trânsito de audiências (OROZCO GÓMEZ, 2011). A finalidade está em acompanhar o percurso da narrativa da telenovela para entender o movimento das representações, via posições de sujeito, que se vinculam ao imaginário de classe social, lidas a partir dos comentários de receptores no Twitter.

1 Doutora e Mestre em Comunicação (UFSM). sandra.depexe@ufsm.br 2 Rede social digital em que os usuários podem enviar mensagens (tweets) com até 140 caracteres, e fazer o uso de marcadores temáticos (hashtags). Disponível em: <www.twitter.com> 


\section{VOZES $_{\text {\&IÁLORO }}^{\mid}$}

Itajaí, v. 18, n. 02, jul/dez 2019

Embora o número de estudos que abordem os sujeitos em relação com a Internet esteja em ascensão (PIENIZ; WOTTRICH, 2014), as pesquisas sobre a recepção de telenovela na internet, em sua maioria, se dedicam a espaços mantidos ou controlados pela instância produtora da telenovela, ou ao exame de determinados perfis de usuários nas redes sociais digitais. Diferentemente, nosso intento se direciona a amplitude dos fluxos de produção e consumo em que se desenvolvem as atividades dos receptores, isto é, na circulação. Assim, "no caso de pensar a circulação no âmbito do consumo, trata-se de identificar como os receptores/consumidores relacionam-se com os conteúdos midiáticos” (JACKS et al., 2011, p. 301-302), apontando tanto para a estabilização quanto para a reformulação de sentidos a respeito de tais produções.

Dessa forma, este texto é excerto de um trabalho maior, e apresenta, como recorte do objeto empírico, a trajetória da personagem Érica (Flávia Alessandra) conjugada aos tweets de receptores. No caso, a representação de classe social dá lugar a outros sentidos quando Érica, uma tenente veterinária, passa a ser designada pelos tweeteiros ${ }^{3}$ como "periguete" - termo utilizado para definir, geralmente, a mulher de classe popular, vista como sensual e com uma moral sexual liberta.

Tomamos como aportes a noção de consumo cultural de Néstor García Canclini, os capitais de Pierre Bourdieu como indicadores das práticas para a leitura da representação de classe social na telenovela, e nos vinculados à análise de discurso desenvolvida por Michel Pêcheux como método de análise dos comentários do Twitter.

\section{Para ler consumo e classe}

Por nos interessar examinar o fluxo livre em que a recepção da telenovela Salve Jorge constrói sentidos sobre classe social e os faz circular em comentários sobre a trama em uma ambiência digital, nos filiamos à perspectiva desenvolvida por Néstor García Canclini, o consumo cultural. Para o autor, o consumo é "o conjunto de processos socioculturais em que se realizam a apropriação e os usos dos produtos” (GARCÍA CANCLINI, 1995, p.53). Optamos por concentrar, neste texto, as atenções aos modelos, apresentados em García Canclini $(1992,1995)$ em que o consumo é visto como distinção e comunicação entre as classes.

O consumo como lugar de diferenciação e distinção entre as classes e os grupos, revela os aspectos simbólicos e estéticos da racionalidade consumidora (GARCÍA CANCLINI, 1995), os quais não se definem apenas pela posse ou uso de determinados objetos, mas pelas maneiras com que eles se transmutam em signos de status. Entretanto, o efeito de sentido de distinção só pode ser alcançado pela compreensão de que ao se diferenciar de uma classe o sujeito se identifica com outra, movimentando os sentidos de

\footnotetext{
${ }^{3}$ Designação para definir os usuários do Twitter.
} 


\section{VOZES $_{\text {\&DÁLORO }}^{\mid}$}

Itajaí, v. 18, n. 02, jul/dez 2019

pertencimento a um grupo. É preciso levar em conta que determinados comportamentos de consumo também favorecem a sociabilidade e a construção da racionalidade integrativa e comunicativa de uma sociedade (GARCÍA CANCLINI, 1995).

Tomamos aporte dos conceitos de habitus, estilo de vida e dos capitais propostos por Pierre Bourdieu para pensar as práticas que distinguem as classes sociais e que permitem filiar as personagens da telenovela em uma dada realidade social a ser interpretada pelo receptor. Bourdieu (2011) metaforiza o conceito de capital, central na teoria marxista, em quatro dimensões: econômica, cultural, social e simbólica. O capital econômico inclui riqueza, renda, heranças financeiras e ativos monetários. O capital cultural pode ser pensado sob três formas: estado corporificado (disposições da mente e do corpo); estado objetivado (bens culturais); estado institucionalizado (qualificações educacionais). Já o capital social se refere à posição ocupada nas relações sociais e, por fim, o capital simbólico diz respeito ao poder simbólico, ao que dá sentido e legitimidade aos demais capitais. Essas metáforas - capitais - permitem avaliar outras importantes dimensões que fogem estritamente da esfera econômica, ainda que possam estar relacionadas e corporificadas no habitus de classe.

Habitus é a noção utilizada por Bourdieu para dar conta da unidade de estilo que vincula as práticas e os bens de um sujeito ou de uma classe. Assim, a cada classe de posições corresponderia uma classe de habitus (ou gostos) produzido pelo condicionamento social. Segundo Bourdieu (1996, p.21-22, grifos do autor), "o habitus é esse principio gerador e unificador que retraduz as características intrínsecas e relacionais de uma posição em um estilo de vida unívoco, isto é, em um conjunto unívoco de escolhas de pessoas, de bens, de práticas”. Cabe ressaltarmos que para Lopes (2009), a telenovela, como "recurso comunicativo4", ativa a correspondência entre o habitus do mundo narrado e o habitus vivido pela recepção, possibilitando o reconhecimento de si e do outro em meio a representações de uma "comunidade nacional imaginada" 5.

A partir do exposto, consideramos a telenovela como produto de consumo cultural e, portanto, sua significação não fica restrita ao momento de assistência, mas encaminha-se à construção de sentidos relacionados a uma gama de bens materiais e comportamentos, os quais são vistos na tela e repercutem no cotidiano da recepção. Logo, se as "personagens servem para o debate, a interpretação, a crítica, a projeção ou a rejeição dos públicos” (LOPES; BORELLI; RESENDE, 2002, p.368), é através delas que iremos ler a elaboração dos sentidos dados ao consumo da telenovela, em seu aspecto distintivo e comunicativo.

\footnotetext{
${ }^{4}$ Trata-se de "reconhecer a telenovela como componente de políticas de comunicação/cultura que perseguem o desenvolvimento da cidadania e dos direitos humanos na sociedade" (LOPES, 2009, p.32).

${ }^{5}$ Lopes (2009) se inspira na noção de "comunidade nacional imaginada" cunhada por Benedict Anderson "para indicar as representações sobre o Brasil veiculadas pelas novelas e as maneiras como produzem referenciais importantes para a reatualização do conceito de nação e de identidade nacional" (LOPES, 2009, p.23).
} 


\section{VOZES $_{\text {\&IÁLORO }}^{\mid}$}

Itajaí, v. 18, n. 02, jul/dez 2019

\section{Indicações teórico-metodológicas}

Pensar a atividade dos receptores de telenovela em uma ambiência digital exige "um remodelamento da recepção da forma como até então era entendida e pesquisada” (PIENIZ; WOTTRICH, 2014, p.75), uma vez que a condição comunicacional contemporânea, como propõe Orozco Gómez (2011), está no trânsito das audiências de receptoras a emissoras.

Observar a circulação da telenovela na internet exige algumas considerações por parte do pesquisador, principalmente ao caráter privado e pessoal que as experiências monitoradas assumem e sua implicação ética (FLICK, 2009). Nesta pesquisa nos dedicamos ao espectro de comentários circulantes na rede sem o contato entre a pesquisadora e os usuários, em que adotamos uma amostra que corresponde a um grupo de receptores não identificados (JACKS, 2014). Embora os materiais coletados estivessem disponíveis em perfis públicos ${ }^{6}$ do Twitter, julgamos ideal manter no anonimato a autoria dos comentários que foram selecionados para o corpus de análise.

Como método de entrada no campo e coleta de dados, optamos pelo monitoramento de mídias sociais, atrelada à técnica de observação sistemática, sempre ao término da exibição dos capítulos, durante os sete meses em que a trama foi ao ar. A estratégia visou acompanhar o movimento da recepção na rede e resultou em mais de 500 mil comentários do Twitter capturados sobre Salve Jorge, sendo aproximadamente seis mil referentes à personagem Érica. O tratamento dos dados seguiu os preceitos da CAQDAS (Computer Aided Qualitative Data Analisys Softwares). O software NVivo 10 foi instrumento para a coleta e, posteriormente, codificação e seleção dos tweets que servem ao corpus analítico.

Nossa leitura acerca dos comentários realizados pela audiência da telenovela no Twitter remete à análise das condições de produção do discurso, as quais dizem respeito aos sujeitos implicados e à situação - entendida como exterioridade linguística - de modo que correspondam a certo lugar no interior de uma formação social dada.

As condições de produção do discurso são explicadas por Pêcheux (2010) através das relações de força, das relações de sentido e do mecanismo de antecipação. As relações de força são exteriores à situação do discurso e instituem que "a mesma declaração pode ser uma arma temível ou uma comédia ridícula segundo a posição do orador e do que ele representa, em relação ao que diz” (PÊCHEUX, 2010, p. 76). As relações de sentido que se manifestam na situação discursiva alertam para as relações entre os discursos, isto é, que

\footnotetext{
${ }^{6}$ Se refere à disponibilidade irrestrita de acesso às postagens realizadas por um usuário no Twitter, em que sequer é necessário possuir uma conta na rede social para visualizar esse tipo de perfil. Os perfis "fechados" são aqueles em que o usuário restringe e controla o acesso a seus dados pessoais e postagens.
} 


\title{
VOZES $_{\text {\&IÁLORO }}^{\mid}$
}

Itajaí, v. 18, n. 02, jul/dez 2019

“o discurso se conjuga sempre sobre um discurso prévio” (PÊCHEUX, 2010, p. 76). Já o mecanismo de antecipação "implica que o orador experimente de certa maneira o lugar de ouvinte a partir de seu próprio lugar de orador” (PÊCHEUX, 2010, p. 76), ou seja, essa antecipação do que o outro vai pensar revela a capacidade do sujeito em articular seu discurso com vistas a produzir determinados efeitos em seu interlocutor.

Esses três elementos - relações de força, relações de sentido, antecipação - são reguladas pelas formações imaginárias. Para Pêcheux (2010, p. 81-82),

\begin{abstract}
o que funciona nos processos discursivos é uma série de formações imaginárias que designam o lugar que $\mathrm{A}$ e $\mathrm{B}$ se atribuem cada um a si e ao outro, a imagem que eles se fazem de seu próprio lugar e do lugar do outro. Se assim ocorre, existem nos mecanismos de qualquer formação social regras de projeção, que estabelecem as relações entre as situações (objetivamente definíveis) e as posições (representações dessas situações).
\end{abstract}

Dessa forma, o que funciona no discurso são as imagens dos sujeitos, isto é, as posições discursivas produzidas pelas formações imaginárias, e não os sujeitos empíricos em si. As formações imaginárias se referem ao ponto de vista do sujeito enunciador em relação ao seu interlocutor e também ao referente (contexto ou situação). Logo, o ponto de vista do receptor/internauta em relação à personagem Érica na telenovela Salve Jorge não escapa do embate entre aquilo que o receptor "espera" da personagem e a posição que essa personagem assume na trama. Neste trabalho, consideramos que as formações imaginárias são vinculadas às representações de classe social e ao modo como os receptores consomem e se apropriam das narrativas teledramaturgas.

Em nosso dispositivo de análise, sugerimos que o habitus, os capitais e o estilo de vida funcionem como instâncias vinculadas às formações imaginárias, visto que "o habitus implica não apenas um sense of one’s place, mas também um sense of other's place" (BOURDIEU, 2004, p. 158 grifos do autor). Esse senso de posições de sujeito, quando examinados à luz das narrativas ficcionais, traz à tona a construção das personagens, os sentidos em oferta ao receptor televisivo e as apropriações realizadas no âmbito do consumo simultâneo no Twitter, como veremos a seguir em um mesmo gesto metodológico de descrição e interpretação.

\section{Érica: ideal de consumo ou periguete?}

Érica, personagem interpretada por Flávia Alessandra, possui relação tensional com a protagonista da trama Morena (Nanda Costa), funcionando, por vezes, como uma antagonista na disputa pelo amor de Théo (Rodrigo Lombardi). O modo como Érica é 


\section{VOZES $_{\text {\&IÁLORO }}^{\mid}$}

Itajaí, v. 18, n. 02, jul/dez 2019

descrita, no site oficial de Salve Jorge ${ }^{7}$, nos traz os primeiros indícios para a compreensão do funcionamento das formações imaginárias (PÊCHEUX, 2010) que incidem sobre ela: "Tenente veterinária do exército. É apaixonada por seu trabalho e pelos cavalos. Orgulhosa e determinada, luta pelo que quer sem ferir nenhum princípio ético.” Ao afirmar que Érica é uma médica veterinária já é automaticamente evocada a formação em curso superior e o pertencimento a uma dada classe social é vinculado à sua ocupação profissional.

Por ser uma militar, a imagem que se projeta a respeito de Érica é também regida por outros sentidos advindos de um lugar comumente representado como masculino, bélico e rude, pois como coloca Bourdieu (2011b, p.78), "a definição de um cargo, sobretudo de autoridade, inclui todo tipo de capacitações e aptidões sexualmente conotadas". Ser militar apresenta a possibilidade de igualdade entre os gêneros no campo do trabalho, mesmo que "as profissões nos sectores do exército, da polícia, dos transportes e dos técnicos apenas marginalmente estão abertas às mulheres” (LIPOVETSKY, 1997, p.241). A imagem de uma mulher moderna, profissional, economicamente ativa e independente é acionada aos moldes de uma heroína moderna (ALMEIDA, 2007).

O estilo de vida (BOURDIEU, 1993) de Érica é discursivamente reforçado e moldado pelos cenários do ambiente de trabalho, de seu apartamento e dos lugares que frequenta. A profissão, as cenas em que lê revistas, e a estante repleta de livros em sua residência aludem a um elevado capital cultural. O capital social da personagem também é elevado, uma vez que transita, de uma forma ou de outra, os grandes núcleos da telenovela. No que se refere ao capital econômico, devemos lembrar que Érica não possui casa própria - ela divide um apartamento com Julinha (Cris Vianna) e Márcia (Fernanda Paes Leme) - e seguidamente utiliza taxi ou pega carona para se deslocar, embora frequente requintados bares, boates e restaurantes. Utilizando as noções de Bourdieu (2011a), podemos dizer que Érica possui maior capital cultural que econômico, podendo ser considerada como pertencente à classe média alta.

É interessante notar que as referências acerca de seu capital cultural e econômico, são pautados, por vezes, pelos receptores no Twitter. Ora elogiam o quadro que está na parede de sua sala, um pôster do filme Volver dirigido por Pedro Almodóvar. Ora questionam sua condição financeira pela comparação de seus hábitos de consumo. Também expõem admiração ou identificam contradição nos fatos apresentados na telenovela e as condições do trabalho militar. Nisso, as associações estabelecidas pelo viés sociocultural do consumo (GARCÍA CANCLINI, 1992, 1995), são capazes de gerar identificação/comunicação e distinção de classe pelo funcionamento das formações imaginárias (PÊCHEUX, 2010) do receptor e o que ele vê representado na telenovela, como exemplificam os tweets $^{8}$ abaixo:

\footnotetext{
${ }^{7}$ Disponível em: < http://tvg.globo.com/novelas/salve-jorge/>. Acesso em: 10 maio 2013.

${ }^{8}$ Optamos por manter a grafia original dos tweets, incluindo erros de escrita, abreviações, sinais gráficos, gírias e onomatopeias para o riso. Igualmente, mantemos em anonimato a origem ou autoria dos comentários.
} 


\section{VOZES $_{\text {\&DÁLORO }}^{\mid}$}

Itajaí, v. 18, n. 02, jul/dez 2019

Quem observou que na casa de Érica, de Salve Jorge, tem um quadro do poster do filme Volver? *_* (4 mar. 2013)

Qual a média de salário de um tenente e um capitão do exército? Cabe no orçamento ir e voltar do trabalho todos os dias de táxi? \#SalveJorge (01 abr. 2013)

Érica vive mal de grana, mas janta no mesmo restaurante que a Lívia \#SalveJorge (15 abr. 2013)

Érica: "EU SOU TENENTE. VETERINÁRIA DO EXÉRCITO." \#Perfeito aaaaaaaaaaaaaaaaaaaaawwnnnnn :3 Meu sonho é de um dia falar isso :D \#SalveJorge (16 maio 2013)

A maneira de se vestir de Érica é regulada pelo lugar que ela ocupa na esfera pública e na esfera privada. Prevalecem na primeira os uniformes militares - com cabelo preso em um coque, botas de cano longo - e na segunda há evocação da sensualidade e da feminilidade em decotes, pernas à mostra, cabelos soltos, maquiagem mais elaborada ou nos saltos altos, como compilamos na Figura 1. Cabe ressaltarmos que a aparência da personagem está mais próxima a uma estética de um padrão de beleza dominante: é branca, loira, alta e magra, que atrelado à classe social que representa, aponta para o imaginário de um ideal feminino (GOLDENBERG, 2011a; MALYSSE, 2008). Portanto, embora sua profissão evoque ao masculino, por uma definição dominante da prática que perpassa a hexis corporal (BOURDIEU, 2011b), Érica não se desvincula da imagem de feminilidade.

Figura 1 - O figurino de Érica

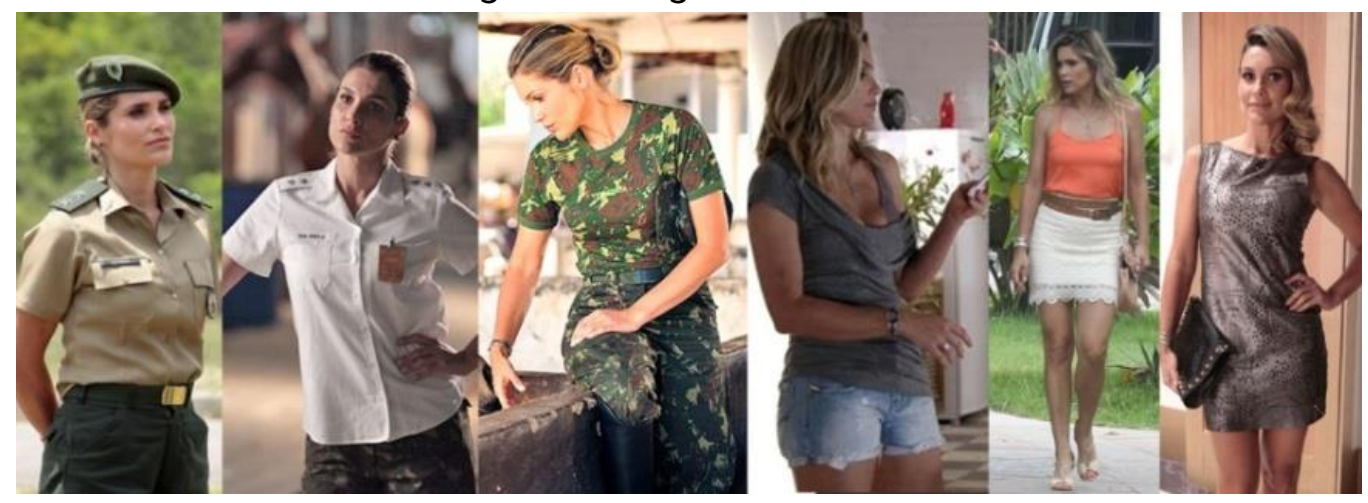

Fonte: imagens de divulgação coletadas do site da Rede Globo

Vale pontuar que os receptores elogiam a beleza de Flávia Alessandra e usem desse expediente, inclusive, para questionar a "falta de sorte" de Érica nos relacionamentos amorosos, como veremos em sequência. Seu corpo torna-se objeto de adoração para homens e mulheres, a exemplo do que Goldenberg (2006, 2011b) identificou em uma pesquisa empírica: na cultura brasileira o desejo, em grande parte, corresponde à estética "norte-europeia”. Nos tweets, que tomamos como exemplo, um rapaz conota que não teria 


\section{VOZES $_{\text {\&IÁLORO }}^{\mid}$}

Itajaí, v. 18, n. 02, jul/dez 2019

se esforçado para ser dispensado do Exército, caso lá tivessem mulheres bonitas, outros a chamam de "deusa" e "gostosa". As mulheres, além de expressar admiração, afirmam invejar e almejar o corpo da atriz, corroborando que a mídia oferta um ideal a ser imitado. Assim,

os corpos e os comportamentos mais imitados na cultura brasileira estão, sem dúvida alguma, nas telenovelas da Rede Globo. Elas podem ser vistas como um reflexo dos corpos e comportamentos existentes na sociedade, mas, ao mesmo tempo, mostram inovações comportamentais e novos estilos de vida (GOLDENBERG, 2011b, p.545).

Os tweets dos receptores nos remetem à noção de consumo como comunicação/identificação, mas, também de aspectos simbólicos e estéticos de uma racionalidade consumidora (GARCÍA CANCLINI, 1995), em que o corpo assume aspecto distintivo. Discursivamente, há identificação entre o corpo da atriz e um modelo a ser alcançado, logo, “'o corpo' é um valor em si, que simultaneamente identifica o indivíduo com um grupo e o distingue dos demais. Esse corpo malhado, esculpido e desenhado constitui uma espécie de prova de virtude" (GOLDENBERG, 2011b, p.552). Uma cena em que a atriz aparece correndo de biquíni na praia, em 12 de março de 2013, é exemplar de como o seu corpo é "incessantemente exposto à objetivação operada pelo olhar e pelo discurso dos outros” (BOURDIEU, 2011b, p.79).

Invejinha básica da barriga da Flávia Alessandra....... Olha issooo!!! \#SalveJorge (12 mar. 2013)

Puta que pariu, que corpo lindo é esse da Flávia Alessandra? A mulé tem duas filhas e tá com tudo em cimaaaa!! (12 mar. 2013)

Flavia Alessandra DEUSA de biquíni \#SalveJorge (12 mar. 2013)

OLHA A COXA DA FLÁVIA ALESSANDRA. NÃO BALANÇA GENTE. NEM CORRENDO. POR FAVOR!!!!!! (12 mar. 2013)

Entretanto, a beleza de Érica não foi suficiente para que seu namorado Théo não se apaixonasse por outra mulher, logo nos primeiros capítulos da telenovela. Durante a exibição de Salve Jorge o romance entre Théo e Érica foi reatado e desfeito várias vezes. No Twitter, os comentários, ao longo da trama, demonstram indignação a cada "ida e vinda" do casal.

E esse papel da Flávia Alessandra? Linda, educada, sendo trocada por uma barraqueira Piriguete! Muito normal nos dias de hoje. \#SalveJorge (29 out. 2012)

a morena de \#SalveJorge não merce o theo, pelo amor de deus, aquela peste periguete devia se entregar pro tráfico de gente.... (29 out. 2012) 


\section{VOZES $_{\text {\&IÁLORO }}^{\mid}$}

Itajaí, v. 18, n. 02, jul/dez 2019

Algum homem (hetero) daqui trocaria a Flavia Alessandra por essa Morena da boca torta? (29 mar. 2013)

Não canso de dizer isso, como é que alguem em sã conscienciência prefere Nanda Costa àh Flávia Alessandra? Tadinha da Érica (02 abr. 2013)

\#SalveJorge Théo deve ter um problema mental de trocar a Érica ( Flávia Alessandra ) pela Morena (02 abr. 2013)

\#AprendiComSalveJorge que trocar a linda Flávia Alessandra pela piriguete do morro pode! \#SalveJorge (17 maio 2013)

No início da trama a oposição entre as duas personagens é posta no Twitter pela qualificação de Érica em relação à Morena. Enquanto aquela é “educada” e "linda”, esta é designada como "periguete”, "mal educada”, "barraqueira”, "peste”, moradora da favela que deveria "se entregar" para o tráfico de pessoas, ou seja, deveria aceitar ser explorada sexualmente. De fato, na trama, Morena se torna vítima do tráfico internacional de mulheres, em que se torna prostituta na Turquia. Entretanto, a personagem não aceita a condição, enfrenta diversas dificuldades e, ao fim da novela, auxilia a polícia a desmantelar a quadrilha que a traficou.

Vale ressalvar que a aparência de Morena é bastante próxima à média da brasileira. Cabelos escuros e cacheados, pele morena, seios pequenos, quadris mais largos, estatura mediana. No figurino, roupas curtas e justas, em que prevalecem shorts e camisetas regatas ou vestidos identificados pelos receptores como pertencentes à estética periguete. Se no princípio, Morena era tida como periguete que teria "seduzido" o capitão do Exército - que nos remete às colocações de Stolke (2006) sobre as associações à sexualidade feminina, cor de pele e classe social - a responsabilidade pelo rompimento com a moça loira, de classe social mais elevada passa a ser de Théo com o andamento da telenovela. Entretanto, essa responsabilidade ainda opera pelo sentido de uma "falta de consciência" que alude a um "problema mental” de Théo. Afinal, quem trocaria "o modelo ideal de mulher" por uma "mulher comum” e, ainda, pobre? Em resumo, as formações imaginárias (PÊCHEUX, 2010) dos receptores mostram o funcionamento da ideologia que conjuga classe e beleza, e que exime o homem de qualquer racionalidade amorosa.

Érica, separada de Théo, se envolveu com outros cinco homens, acionando de forma mais completa a imagem das heroínas modernas: "mulheres que têm sua profissão, são economicamente ativas e independentes, têm vida sexual ativa e feliz, relacionam amor a prazer e realização sexual” (ALMEIDA, 2007, p.183). Entretanto, a liberdade sexual de Érica não é bem vista pelos receptores, provavelmente por escapar do ideal romântico que a conduziria ao "final feliz" e ao casamento. Pelo contrário, a personagem inicia vários namoros que não dão certo.

No capítulo de 4 de março de 2013, Érica vai a um jantar na casa de Celso (Caco Ciocler), para ser apresentada à família dele, e os acontecimentos demonstram o quanto 


\section{VOZES $_{\text {\&IÁLORO }}^{\mid}$}

Itajaí, v. 18, n. 02, jul/dez 2019

os sentidos acerca da representação da mulher são flutuantes. No Twitter, o embate se dá a respeito da roupa e maquiagem de Érica, em que é elogiada por alguns e fortemente rebatida por outros receptores.

Essa maquiagem ta Flavia Alessandra ta liinda *** \#SalveJorge (04 mar. 2013)

Que make divaaa érica! \#salvejorge (04 mar. 2013)

Érika que make pesada hein !!! Menos é mais !!! \#SalveJorge (04 mar. 2013)

Que linda a roupa da Tenente Éricka \#SalveJorge (04 mar. 2013)

A tenente vai ver so futuros sogros com um vestido de piriguete? Falha no engano, produção. \#SalveJorge (04 mar. 2013)

Quem vai conhecer os sogros com essa saia minúscula que a Flávia Alessandra está usando? \#SalveJorge (04 mar. 2013)

Flavia Alessandra com sainha de biscate para conhecer os sogros. Ai! \#SalveJorge (04 mar. 2013)

Não há um consenso sobre o quão adequada ou inadequada é a maquiagem e a roupa de Érica para a ocasião. Interessa-nos observar como a mesma composição visual, para uma mesma mulher, em que todos receptores têm relativamente o mesmo conhecimento sobre sua trajetória, repercute de diferentes formas. $\mathrm{O}$ que distingue a personagem como "diva" e "linda" de "periguete" e "biscate"? O modo como as formações imaginárias (PÊCHEUX, 2010) são acionadas indicam a presença da ideologia, de que a personagem deveria se portar de uma forma em específico, isto é, há um padrão de conduta esperado - ou como diz-nos Bourdieu (2011b, p.81), "esquemas fundamentais nascidos da incorporação das estruturas sociais”-, que, em nosso entendimento, é marcado pelo imaginário sobre a mulher e sobre a classe social a qual ela pertence.

A moralidade implícita no vestuário reverbera historicamente, como mostra Souza (1987), nas tentativas da mulher burguesa, no século XIX, em conseguir um casamento. A roupa, os ornamentos e os modos de ser, multiplicados nas revistas e livros da época, eram tidos como arsenais femininos para aprimoramento da arte da sedução. Assim, a mulher se colocava em um jogo de entrega e recuo para, "sem ofender a moral burguesa de guardar as aparências, oferecer-se ao mesmo tempo a uma quantidade de homens” (SOUZA, 1987, p.95).

Podemos associar esse acontecimento discursivo em referência a García Canclini (1992, 1995) e ao consumo como identificação e distinção. A vestimenta de Érica é aprovada por quem se enquadra naquelas disposições e rechaçada por aqueles que veem na saia curta uma espécie de afronta ao ritual de “conhecer a família do namorado". É possível que colada à comunicação dessa identificação, estejam aqueles receptores - mas 


\section{VOZES $_{\text {\&IÁLORO }}^{\mid}$}

Itajaí, v. 18, n. 02, jul/dez 2019

não de forma exclusiva - que admiram a atriz e vejam nela um exemplo para imitação, como já comentamos. Em todo caso, a cena e sua repercussão não deixam dúvidas de que a apropriação da telenovela ocorre de modo distinto aos seus receptores.

Ao longo da exibição de Salve Jorge, os comentários capturados no Twitter apontam para diferenças na compreensão das relações de gênero, especialmente nos relacionamentos afetivos e nas formas de mostrar o corpo. A formação ideológica (PÊCHEUX, 2010) na qual Érica se inscreve é a de uma mulher de classe média alta, que por ser tenente do Exército é implicada pela questão de ordem, moral e seriedade. Entretanto, a personagem é designada por periguete quando utiliza uma saia curta em uma situação considerada inapropriada e outras vezes por referência a troca de namorados. Grávida, até mesmo a paternidade de seu filho é questionada pelos receptores.

Érica revela: Sou piriguete. Dei na cama do Élcio. \#SalveJorge (08 jan. 2013)

E a Érica vai rodar todos os núcleos? Depois o pessoal do alemão que é piriguete! \#SalveJorge (16 fev. 2013)

Não sei se essa Erica é santa ou é piriguete! \#salvejorge \#traficadas (01 mar. 2013)

nossa, Érica de Salve Jorge é uma galinha, hein? fala sério, que piriguete.. (12 mar. 2013)

Esqueceram que Érica pegou o Élcio, o namorado que não lembro o nome, e um militar gaúcho. Théo devia pedir DNA pro Ratinho \#SalveJorge (02 abr. 2013)

$\mathrm{E}$ a vet-tenente, depois de passar pelas mãos de TODOS os homens da novela, vai acabar com o próprio marido. Glória, a irônica. \#salvejorge (16 maio 2013)

De modo geral, a leitura possível, é de que Érica é vista prioritariamente pela posição que ocupa socialmente, vivendo na linha tênue entre a independência feminina e o fracasso nos assuntos amorosos. O discurso implícito reproduz o imaginário de herança patriarcal de que a felicidade da mulher só é alcançada ao lado de um homem. A moderna Érica, que trabalha em um ambiente masculino e se relacionou com seis parceiros diferentes em toda a trama, é reprimida no exercício de sua liberdade sexual e castigada por um amor não correspondido. Ao final da telenovela, Érica tem um final feliz com o advogado Haroldo (Otaviano Costa), que a atropelou e fez com que a moça perdesse o filho que esperava de Théo. O ator que interpreta Haroldo é, na vida real, esposo de Flávia Alessandra, coincidência que também foi muito comentada no Twitter. 


\section{VOZES $_{\text {\&IÁLORO }}^{\mid}$}

Itajaí, v. 18, n. 02, jul/dez 2019

\section{Considerações finais}

Compreendemos que os tweets coletados e analisados servem como indícios das elaborações e apropriações que a recepção televisiva faz do texto da telenovela, as quais não ficam restritas apenas ao contexto da narrativa midiática, mas se relacionam com $o$ cotidiano dos sujeitos, bem como confrontam suas crenças, valores e imaginários. A heterogeneidade de sentidos que a recepção põe em circulação nos mostra o quão delicado ainda são alguns temas e o quanto alguns pré-conceitos sobre classe social e sobre a mulher ainda são arraigados na cultura brasileira. Uma mulher usar farda é permitido. Uma mulher usar uma minissaia, em algumas situações, provoca a linha tênue da moralidade e do julgamento.

Érica é representada na dualidade entre a vida profissional e a vida particular de uma mulher de classe média alta. Trabalha no Exército Brasileiro, uma instituição ainda fortemente associada ao masculino. A aparência da personagem condiz ao padrão de beleza - branca, loira, alta e magra - e seu estilo de vida indica que seu maior capital é o cultural, dada a formação em nível superior e a mobília de seu apartamento. Entretanto, os comentários no Twitter mostram que o imaginário positivo acerca do padrão hegemônico é rompido. A mulher ainda é duplamente repreendida: seu corpo é aprovado como objeto ao consumo, mas não deve servir ao seu próprio prazer. Ser designada como periguete remete às características comportamentais e morais, uma dada forma de se vestir e de experienciar a sexualidade, o qual entra em conflito com o ideal profissional, com a classe e estética representada pela personagem. A recepção, em parte, aprova o ideário de uma mulher moderna, em outra, reforça um modelo de conduta conservador.

\section{Referências}

ALMEIDA, H. B. Consumidoras e heroínas: gênero na telenovela. Estudos Feministas, v. 15, n. 1, p. 177-192, 2007.

BOURDIEU, P. Gostos de classe e estilos de vida. In: ORTIZ, R. (Org.). Pierre Bourdieu: sociologia. São Paulo: Ática, 1993. p. 82-121.

BOURDIEU, P. Razões práticas: sobre a teoria da ação. Campinas: Papirus, 1996.

BOURDIEU, P. Coisas ditas. São Paulo: Brasiliense, 2004.

BOURDIEU, P. A distinção: crítica social do julgamento. 2. ed. Porto Alegre: Zouk, 2011a.

BOURDIEU, P. A dominação masculina. 10. ed. Rio de Janeiro: Bertrand Brasil, 2011b. 


\section{VOZES $_{\text {\&IÁLORO }}^{\mid}$}

Itajaí, v. 18, n. 02, jul/dez 2019

FLICK, U. Introdução à pesquisa qualitativa. 3. ed. Porto Alegre: Artmed, 2009.

GARCÍA CANCLINI, N. Los estudios sobre comunicación y consumo: el trabajo interdisciplinário en tiempos neoconservadores. Dialogos de la comunicación, n. 32, p. 26, 1992. Disponível em: <http://www.dialogosfelafacs.net/wp-content/uploads/2011/10/ 32.pdf>.

GARCÍA CANCLINI, N. Consumidores e cidadãos: conflitos multiculturais da globalização. Rio de Janeiro: Editora UFRJ, 1995.

GOLDENBERG, M. O corpo como capital: para compreender a cultura brasileira. Arquivos em Movimentos, v. 2, n. 2, p. 115-123, 2006.

GOLDENBERG, M. Afinal, o que quer a mulher brasileira? Psicologia Clínica, v. 23, n. 1, p. 47-64, 2011a.

GOLDENBERG, M. Gênero, “o corpo" e "imitação prestigiosa” na cultura brasileira. Saúde e Sociedade, v. 20, n. 3, p. 543-553, 2011 b.

JACKS, N. et al. Telenovela em múltiplas telas: da circulação ao consumo. In: LOPES, M. I.V. (Org.). Ficção televisiva transmidiática no Brasil: plataformas, convergência, comunidades virtuais. Porto Alegre: Sulina, 2011. p. 297-338.

JACKS, N. (Org.). Meios e audiências II: a consolidação dos estudos de recepção no Brasil. Porto Alegre: Sulina, 2014.

LIPOVETSKY, G. A terceira mulher: permanência e revolução do feminino. Tradução Maria João Batalha Reis. Lisboa: Instituto Piaget, 1997.

LOPES, M.I. V.; BORELLI, S. H. S.; RESENDE, V. R. Vivendo com a telenovela: mediações, recepção, teleficcionalidade. São Paulo: Summus, 2002.

LOPES, M. I.V. Telenovela como recurso comunicativo. Matrizes, v. 3, n. 1, p. 21-47, 2009 .

MALYSSE, S. A moda incorporada: antropologia das aparências corporais e megahair. In: OLIVEIRA, A. C.; CASTILHO, K. (Org.). Corpo e moda: por uma compreensão do contemporâneo. Barueri-SP: Estação das Letras e Cores Editora, 2008. p. 105-124.

OROZCO GÓMEZ, G. La condición comunicacional contemporánea. Desafíos latinoamericanos de La investigación de las interacciones en la sociedad red. In: JACKS, N. et al. (Org.). Análisis de recepción en América Latina: un recuento histórico con perspectivas al futuro. Quito-Ecuador: CIESPAL, 2011. p. 377-408.

PÊCHEUX, M. Análise automática do discurso (AAD-69). In: GADET, F.; HAK, T. (Org.). Por uma análise automática do discurso: uma introdução à obra de Michel Pêcheux. 4. ed. Campinas: Editora da Unicamp, 2010. p. 59-158. 


\section{VOZES $_{\text {\&IÁLORO }}^{\mid}$}

Itajaí, v. 18, n. 02, jul/dez 2019

PIENIZ, M.; WOTTRICH, L. H. Receptores na Internet: desafios para o contexto de trânsito das audiências. In: JACKS, Nilda (Org.). Meios e audiências II: a consolidação dos estudos de recepção no Brasil. Porto Alegre: Sulina, 2014. p. 73-94.

SOUZA, G. M. O espírito das roupas: a moda no século dezenove. São Paulo: Companhia das Letras, 1987.

STOLKE, V. O enigma das interseções: classe, "raça”, sexo, sexualidade: a formação dos impérios transatlânticos do século XVI ao XIX. Revista Estudos Feministas, v. 14, n. 1, p. $15-42,2006$. 